\title{
Karakteristik Komite Audit pada Audit Report Lag
}

\section{Cokorda Istri Mas Pradnyadari Pemayun ${ }^{1}$ \\ Fakultas Ekonomi dan Bisnis Universitas Udayana, Indonesia}

\author{
Ida Bagus Putra Astika ${ }^{2}$ \\ Fakultas Ekonomi dan Bisnis \\ Universitas Udayana, Indonesia
}

\begin{abstract}
Surel : cokistrimas@yahoo.com
\section{ABSTRAK}

Penelitian ini menguji hubungan antara karakteristik Komite audit dengan Audit Report Lag. Karakteristik komite audit diukur dengan beberapa variabel, yaitu ukuran komite audit, independensi komite audit, dan rapat komite audit. Peneliatian ini dilaksanakan pada perusahaan manufaktur yang terdaftar di Bursa Efek Indonesia tahun 2014-2016. Jumlah sampel yang digunakan dalam penelitian ini sebanyak 44 perusahaan yang diperoleh dengan metode purposive sampling. Teknik analisis data dilakukan dengan menggunakan teknik analisis regresi linier berganda. Berdasarkan hasil analisis, menunjukan bahwa karakteristik komite audit yang diukur dengan ukuran komite audit berpengaruh negatif signifikan pada audit report lag. Penelitian ini juga menemukan bahwa independensi komite audit berpengaruh postitif dan rapat komite audit tidak berpengaruh pada audit report lag.
\end{abstract}

Kata Kunci: Ukuran Komite Audit; Independensi Komite Audit; Rapat Komite Audit; Audit Report Lag.

\section{Characteristics of the Audit Committee on the Audit Report Lag}

\section{ABSTRACT}

This study examines the relationship between the characteristics of the Audit Committee and Audit Report Lag. Audit committee characteristics are measured by several variables, namely the size of the audit committee, the independence of the audit committee, and the audit committee meeting. This research was carried out on manufacturing companies listed on the Indonesia Stock Exchange in 2014-2016. The number of samples used in this study were 44 companies obtained by purposive sampling method. Data analysis techniques were carried out using multiple linear regression analysis techniques. Based on the results of the analysis, it shows that the audit committee characteristics as measured by the size of the audit committee have a significant negative effect on audit report lag. This study also found that the independence of the audit committee had a positive influence and the audit committee meeting had no effect on audit report lag.

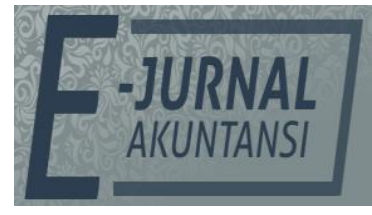

e-ISSN 2302-8556

Vol. 31 No. 1

Denpasar, Januari 2021

Hal. 152-167

DOI:

10.24843/EJA.2021.v31.i01.p12

PENGUTIPAN:

Pemayun, C.I.M.P., \& Astika, I.B.P. (2021). Karakteristik Komite Audit pada Audit Report Lag. E-Jurnal Akuntansi, 31(1), 152-167

RIWAYAT ARTIKEL:

Artikel Masuk: 6 November 2018 Artikel Diterima: 20 Januari 2020

Keywords: Audit Committee Size; Audit Committee Independence; Audit Committee Meeting; Audit Report Lag.

Artikel dapat diakses : https://ojs.unud.ac.id/index.php/Akuntansi/index 


\section{PENDAHULUAN}

Perkembangan perusahaan publik di Indonesia telah mengalami kemajuan yang pesat. Peristiwa ini menimbulkan konsekuensi dibutuhkannya pendanaan yang lebih besar bagi aktivitas investasi dan operasional perusahaan. Sumber pendanaan bagi perusahaan dapat diperoleh dari investor dan kreditor, di mana kedua pihak membutuhkan informasi keuangan untuk mengambil keputusan yang bisa diperoleh dari laporan keuangan.

Laporan keuangan merupakan hasil akhir dari suatu proses pencatatan, yang merupakan suatu ringkasan dari transaksi-transaksi keuangan yang terjadi selama tahun buku yang bersangkutan. Laporan keuangan memuat catatancatatan tentang kegiatan bisnis yang dilakukan oleh sebuah entitas dalam suatu periode tertentu (Toding, 2013). Pada pasar modal laporan keuangan yang telah diaudit menjadi salah satu sumber informasi terpercaya dibandingkan dengan sumber informasi lain yang tersedia di pasar modal (Ahmed \& Hossain, 2010). Laporan keuangan dasar untuk menyusun perencanaan kegiatan perusahan, mengendalikan perusahaan, dasar pembuatan keputusan, bahan pertimbangan dan pertanggungjawaban terhadap pihak eksternal. Laporan keuangan ini dibuat dengan tujuan memberikan informasi yang berkaitan dengan posisi keuangan perusahaan, hasil usaha perusahaan, dan perubahan posisi keuangan perusahaan. Diharapkan para pengguna laporan keuangan dapat menilai informasi yang disajikan sebagai dasar membuat keputusan ekonomi yang berhubungan dengan perusahaan tersebut (Ghozali \& Chariri, 2007).

Suatu informasi dikatakan bermanfaat apabila informasi tersebut disampaikan secara cepat, tepat, dan akurat (Megayanti, 2015). Bonson-Ponte et al. (2008) mengatakan bahwa investor membutuhkan informasi yang reliabel dan tepat waktu untuk mengambil keputusan. Salah satu informasi yang terkandung dalam laporan keuangan adalah tingkat kinerja manajemen perusahaan, yang tercermin pada laba dalam laporan laba rugi. Pelaporan keuangan yang tepat pada waktunya akan menghasilkan informasi keuangan yang relevan (Abdelsalam \& Street, 2007). Dyer \& Hugh (1975) menyatakan bahwa manajemen perusahaan besar, memiliki dorongan untuk mengurangi masalah audit report lag dan penundaan laporan keuangan. Manajemen sering mengalami kendala ketika harus menyajikan laporan keuangan tepat waktu, salah satunya laporan keuangan yang harus diaudit terlebih dahulu oleh akuntan publik. Dyer \& Hugh (1975) dalam penelitiannya menyatakan penyebab lamanya pengauditan oleh pihak eksternal dipengaruhi oleh faktor ketidaksepakatan antara manajemen klien dengan auditor. Bamber \& Schoderbek (1993) menyatakan ketidaksepakatan antara manajer perusahaan dengan auditor independen sering disebabkan karena adanya konflik kepentingan antar dua belah pihak (agency problem). Manajemen perusahaan cenderung ingin menutupi kelemahan kinerjanya demi mempertahankan citra yang baik di mata principal, Sedangkan auditor independen dengan adanya tuntutan kode etik profesinya, berusaha untuk menjalankan tugasnya dengan sebaik mungkin.

Kasus yang berkaitan dengan agency problems di Indonesia, yakni Kimia Farma melakukan mark up laba sebesar Rp 32,688 miliar (Kompas, 5 November 2002) dan kasus Lippo Bank yang menyusun laporan keuangan dalam tiga versi (Asri, 2012). Hal ini memaksa pemerintah untuk membuat keputusaan tegas 
dalam mengatasi masalah yang sejenis ini terus bermunculan. Salah satunya dengan mencanangkan GCG (Good Corporate Governance) pada tahun 2000 (Djakman \& Chaerul, 2003). Implementasi dari program ini adalah dengan mewajibkan perusahaan go public untuk membentuk komite audit yang betugas untuk membantu dewan komisaris dalam memastikan transparansi perusahaan. Keberadaan komite audit dengan keahlian keuangan diharapkan dapat menganalisis kesalahan yang berkaitan dengan standar dan prosedur akuntansi teknikal (DeZoort \& Salterio, 2001).

Audit adalah salah satu bentuk dari pemeriksaan yang bersifat membantu agar sasaran yang ditetapkan organisasi dapat tercapai, dan menghindari adanya kebocoran, pemborosan, dan penyimpangan wewenang. Dalam penyajian laporan keuangan sejumlah instansi melakukan kegiatan auditing dari auditorauditor yang ada dengan pengawasan komite audit yang dibentuk oleh dewan komisaris yang nantinya komite audit membantu dewan komisaris melakukan pemeriksaan yang dianggap perlu terhadap pelaksanaan fungsi direksi dalam kepengelolaan perusahaan. Laporan keuangan dapat dipublikasikan ke publik setelah laporan tersebut diperiksa oleh auditor (Indriyani, 2012). Auditing adalah pemeriksaan oleh pihak independen terhadap laporan keuangan yang disusun manajemen secara kritis dan sistematis termasuk catatan dan bukti pendukung yang ada (Sukrisno, 2004:3). Tujuan audit laporan keuangan yaitu untuk menyatakan pendapat atas kewajaran asersi-asersi yang terdapat dalam laporan keuangan sesuai dengan prinsip akuntansi berterima umum (Mulyadi, 2002:72).

Komite audit adalah sebuah komite yang dibentuk oleh dewan komisaris (Kumara, 2015). Dalam hal ini komite audit membantu dewan komisaris untuk memenuhi tanggung jawab pengawasannya, yang meliputi penelaahan atas laporan tahunan auditan dan laporan keuangan, penelahaan terhadap proses pelaporan keuangan dan sistem pengendalian internal, serta pengawasan atas proses audit. Komite audit diharapkan dapat membangun kembali kepercayaan publik dalam pelaporan keuangan serta meningkatkan kualitas audit (Dewiyani, 2013). Dalam kapasitasnya komite audit bertanggung jawab untuk membuka dan memelihara atau menjaga komunikasi antara komite audit dengan dewan komisaris, direksi, unit audit internal, akuntan independen dan manajer keuangan. Selain itu, tugas komite audit meliputi menelaah kebijakan akuntansi yang diterapkan oleh perusahaan, menilai pengendalian internal, menelaah sistem pelaporan eksternal dan kepatuhan terhadap peraturan (Suaryana,2007). Dilihat dari sisi keanggotaan, anggota komite audit diangkat dan diberhentikan oleh dewan komisaris dan dilaporkan pada saat rapat umum pemegang saham.

Mengingat bahwa komite audit didasarkan oleh best practices diharapkan dapat menjadi faktor penguat dalam sistem pelaporan keuangan, penelitian ini mencoba untuk menyajikan bukti empiris hubungan antara komite audit dengan audit report lag. Audit Report Lag adalah interval jumlah hari antara tanggal laporan keuangan tahunan sampai dengan tanggal publikasi yang tertera di laporan auditor independen (Khasharmeh \& Aljifri, 2010). Selain komite audit, juga diselidiki apakah proporsi independensi komite audit dan rapat komite audit memiliki pengaruh terhadap audit report lag.

Keanggotaan Komite Audit diatur dalam surat keputusan Direksi PT Bursa Efek Jakarta Nomor Kep-315/BEJ/06/2000 dan Peraturan BAPEPAM No. IX.I.5: 
Pembentukan dan Pedoman Pelaksanaan Kerja Komite Audit, Lampiran Keputusan Ketua Bapepam No: Kep-29/PM/2004 yang diterbitkan pada 24 Desember 2004 bagian C yaitu anggota Komite Audit sekurang-kurangnya 3 (tiga) orang anggota. Keefektifan komite audit akan meningkat seiring dengan bertambahnya ukuran komite audit, karena komite audit memiliki sumber daya yang memadai untuk mengatasi potensi masalah pelaporan keuangan (Antle \& Nalebuff, 1991). Keberagaman jumlah anggota komite audit pada perusahaan publik di Indonesia bermacam-macam, hal ini yang menimbulkan presepsi bahwa semakin banyak anggota komite audit dapat lebih cepat dalam menemukan serta menyelesaikan potensi masalah yang terjadi dalam proses pelaporan keuangan sehingga dapat megurangi audit report lag. Semakin besar ukuran komite audit maka akan semakin meningkatkan kualitas pengawasan (Naimi 2010).

Komite audit memiliki peran dalam mengawasi pihak manajemen (agent) agar tidak melakukan tindakan yang dapat menguntungkan dirinya sendiri sehingga dapat merugikan pemilik perusahaan (prinsipal). Salah satu dari karakteristik komite audit yang dapat meningkatkan fungsi pengawasan adalah independensi. Anggota komite audit yang independen akan memastikan pelaporan keuangan yang lebih berkualitas. Salah satu tujuan dari komite audit adalah untuk memberikan ulasan objektif tentang informasi keuangan dan komite audit independen dapat berkontribusi terhadap kualitas pelaporan keuangan (Kirk, 2000). Komite Audit Independen diharapkan mampu mengurangi audit report lag yang terjadi.

Dalam mengawasi proses auditing, komite audit akan mengadakan pertemuan untuk rapat secara periodik dan dapat mengadakan rapat tambahan atau rapat-rapat khusus bila diperlukan. Pertemuan secara periodik ini ditetapkan oleh komite audit sendiri dan dilakukan sekurangkurangnya tiga sampai empat kali dalam satu tahun untuk melaksanakan kewajiban dan tanggungjawabnya. Hasil rapat komite audit dituangkan dalam risalah rapat yang ditandatangani oleh semua anggota komite audit. Adanya intensitas pertemuan yang cukup tinggi oleh komite audit diharapkan dapat mempersingkat audit report lag (Sari \& Ghozali 2014). Rapat Komite Audit diharapkan mampu mengurangi audit report lag yang terjadi.

Penelitian mengenai komite audit ini didasari oleh agency theory (teori keagenan). Teori keagenan merupakan dasar yang digunakan perusahaan untuk memahami corporate governance. Hal yang dibahas dalam teori ini adalah hubungan antara pemilik dan pemegang saham (principal) dan manajemen (agent). Dalam hal ini hubungan keagenan merupakan sebuah kontrak antara satu orang atau lebih yang mempekerjakan orang lain untuk memberikan suatu jasa dan kemudian mendelegasikan wewenang pengambilan keputusan kepada agent tersebut (Jensen \& Meckling, 1976).

Teori keagenan dilandasi oleh beberapa asumsi. Asumsi-asumsi tersebut dibedakan menjadi tiga jenis, yaitu asumsi tentang sifat manusia, asumsi keorganisasian dan asumsi informasi. Asumsi sifat manusia menekankan bahwa manusia memiliki sifat mementingkan diri sendiri (self-interest), manusia memilika daya pkir terbatas mengenai persepsi masa mendatang (bounded rationality), dan manusia selalu menghindari resiko (risk averse). Asumsi 
keorganisasian adalah adanya konflik antara anggota organisai, efisiensi sebagai criteria efektifitas dan adanya asimetri informasi antara principal dan agent. Asumsi informasi adalah bahwa informasi sebagai barang komoditi yang dapat diperjual belikan.

Berdasarkan asumsi sifat dasar manusia dijelaskan bahwa masing-masing individu semata-mata termotivasi oleh kepentingan dirinya sendiri sehingga manimbulkan konflik kepentingan antar principal dan agen. Pihak pemilik (principal) termotivasi mengadakan kontrak untuk mensejahterakan dirinya denagan profitabilitas yang selalu meningkat. Sedangkan manager (agent) termotivasi untuk memaksimalkan pemenuhan ekonomi dan psikologisnya, antara lain dalam hal memperoleh investasi, pinjaman, maupun kontrak kompensasi. Dengan demikian terdapat dua kepentingan yang berbeda di dalam perusahaan dimana masing-masing pihak berusaha untuk mencapai atau mempertahankan tingkat kemakmuran yang dikehendaki.

Permasalahan yang timbul akibat adanya perbedaan kepentingan antara principal dan agent disebut dengan agency problems. Salah satu penyebab agency problems adalah adanya asymmetric information. Asymmetric information adalah ketidaksinambungan informasi yang dimiliki principal dan agent, ketika principal tidak memiliki informasi yang cukup tentang kinerja agen sebaliknya, agent memiliki lebih banya informasi mengenai kapasitas diri, lingkunagan kerja dan perusahaan secara keseluruhan (Wijaya, 2012).

Teori agensi digunakan untuk membantu komite audit untuk memahami konflik kepentingan yang dapat muncul antara pemilik dan manajemen. Pemilik selaku investor bekerjasama dan menandatangani kontrak kerja dengan manajemen perusahaan untuk menginvestasikan dana mereka. Dengan adanya komite audit yang independen diharapkan tidak terjadi kecurangan dalam laporan keuangan yang disusun oleh manajemen yang dapat mengakibatkan audit report lag. Sekaligus dapat mengevaluasi kinerja manajemen sehingga akan menghasilkan laporan keuangan yang berguna bagi investor dalam pengambilan keputusan.

Laporan Keuangan memiliki peran penting dalam mengukur kinerja suatu perusahaan karena didalam laporan keuangan tersedia informasi mengenai posisi keuangan, kinerja perusahaan, serta perubahan posisi keuangan suatu perusahaan dimana informasi tersebut sangat bermanfaat untuk sejumlah pemakai informasi potensial dalam hal pengambilan keputusan. Standar akuntansi keuangan menurut Ikatan Akuntan Indonesia (IAI, 2012) mendefinisikan laporan keuangan sebagai berikut: Laporan keuangan merupakan bagian dari pelaporan keuangan. Laporan keuangan yang lengkap biasanya meliputi neraca, laporan laba rugi, laporan perubahan posisi keuangan yang dapat disajikan dalam berbagai cara, misalnya sebagai laporan arus kas atau laporan arus dana, catatan dan laporan ini serta materi penjelasan yang merupakan bagian integral dari laporan keuangan.

Selain itu juga termasuk skedul-skedul dan informasi tambahan yang berkaitan dengan laporan tersebut, misalnya informasi keuangan segmen industri dan geografis, serta pengungkapan pengaruh perubahan harga, sedangkan Pengertian laporan keuangan yang disampaikan oleh Rahardja (2001:45) menyebutkan bahwa laporan keuangan merupakan laporan 
pertanggungjawaban yang telah dibuat oleh manajer atau pimpinan perusahaan atas pengelolaan perusahaaan yang dipercayakan kepadanya oleh pemilik, pemerintah atau kreditor, dan pihak-pihak yang berkepentingan. Standar Akuntansi Keuangan (IAI, 2012) menyatakan bahwa Kerangka Dasar Penyusunan dan Penyajian Laporan Keuangan terdapat empat karakteristik kualitatif laporan keuangan yang dapat berguna bagi para pemakainya. Keempat karakteristik kualitatif informasi tersebut yaitu dapat dipahami (understandbility), relevan (relevance), andal (realibilty), dan dapat diperbandingkan (comparibility).

Afify, (2009) menyatakan Audit Report Lag merupakan interval waktu dari tanggal tutup buku laporan keuangan tahunan sampai dengan tanggal yang tertera di laporan auditor independen atau dalam beberapa penelitian dinyatakan sebagai audit delay. Audit Report Lag juga dapat dikatakan sebagai periode waktu antara akhir tahun fiskal dan tanggal laporan audit perusahaan (Knechel \& Payne, 2001). Semakin lama auditor meyelesaikan pekerjaan auditnya maka semakin panjang audit report lag.

Lampiran Keputusan Ketua Bapepam Nomor: Kep/36/PM/2003 mengatur tentang jangka waktu diterbitkannya laporan keuangan di Indonesia. Badan Pengawas Pasar Modal (Bapepam) di Indonesia mengatur bahwa perusahaan publik wajib menyerahkan laporan keuangan tahunan disertai dengan opini auditor paling lambat pada akhir bulan ketiga setelah tanggal laporan keuangan atau harus teraudit selama 90 hari (Lianto \& Budi, 2010). Menurut Petronila (2007), dalam pelaksanaannya tidak jarang pemeriksaan audit menemui banyak kendala misalnya terbatasnya jumlah karyawan yang melakukan audit, banyaknya transaksi yang harus diaudit, kerumitan dari transaksi dan pengendalian intern yang kurang baik. Hal inilah yang menyebabkan laporan audit dikeluarkan lebih lama dari batas waktu yang ditentukan.

Keanggotaan Komite Audit diatur dalam surat keputusan Direksi PT Bursa Efek Jakarta Nomor Kep-315/BEJ/062000 dan Peraturan BAPEPAM No. IX.I.5 : Pembentukan dan Pedoman Pelaksanaan Kerja Komite Audit, Lampiran Keputusan Ketua Bapepam No: Kep-29/PM/2004 yang diterbitkan pada 24 Desember 2004 bagian C yaitu anggota Komite Audit sekurang-kurangnya 3 (tiga) orang anggota. Jumlah keanggotaan komite audit yang lebih besar akan mampu bekerja lebih efektif guna mengawasi jalannya pelaporan keuangan oleh manajemen perusahaan (Choi J, et al., 2004). Keanggotaan komite audit di Indonesia beragam disesuaikan dengan ukuran atau besar kecilnya organisasi serta tanggung jawabnya. Namun, jumlah keanggotaan tiga samapai lima merupakan jumlah yang cukup ideal (Wijaya, 2012).

Keberagaman jumlah anggota komite audit pada perusahaan publik di Indonesia bermacam-macam, hal ini yang menimbulkan presepsi bahwa semakin banyak anggota Komite Audit dapat lebih cepat dalam menemukan serta menyelesaikan potensi masalah yang terjadi dalam proses pelaporan keuangan sehingga dapat megurangi Audit Report Lag. Salah satu tugas komite audit berkordinasi kepada auditor eksternal dengan tujuan menghasilkan laporan keuangan perusahaan secara wajar (Azibi et al., 2008). Menurut Naimi (2010) bahwa semakin besar ukuran komite audit maka akan semakin meningkatkan kualitas pengawasan. 
Komite audit memiliki peran dalam mengawasi pihak manajemen (agen) agar tidak melakukan tindakan yang dapat menguntungkan dirinya sendiri sehingga dapat merugikan pemilik perusahaan (prinsipal). Salah satu karakteristik komite audit yang dapat meningkatkan fungsi pengawasan adalah independensi. Anggota komite audit yang independen akan memastikan pelaporan keuangan yang lebih berkualitas.

Independensi adalah sikap tidak mudah dipengaruhi, karena auditor melaksanakan pekerjaannya untuk kepentingan umum (Sukrisno, 2012). Selain itu independensi juga berarti sikap mental yang bebas dari pengaruh, tidak dikendalikan oleh pihak lain, serta tidak bergantung pada orang lain. Independensi juga berarti adanya kejujuran dalam mempertimbangkan fakta dan adanya pertimbangan objektif. Independensi anggota komte audit dapat dilihat dari persyaratan keanggotaan komite audit seperti tertuang dalam peraturan No. IX.1.5 tentang pembentukan dan pedoman pelaksanaan kerja komite audit, lampiran ketua Bapepam No. 29/PM/2000.

Peraturan BAPEPAM No. IX.I.5: Pembentukan dan Pedoman Pelaksanaan Kerja Komite Audit, Lampiran Keputusan Ketua Bapepam No: Kep-29/PM/2004 yang diterbitkan pada 24 Desember 2004 bagian C yaitu anggota komite audit sekurang-kurangnya 3 (tiga) orang anggota. Keanggotaan komite audit di Indonesia beragam, disesuaikan dengan ukuran besar-kecilnya organisasi serta tanggung jawabnya. Keanggotaan komite audit memiliki peran penting untuk memantau pengendalian internal dan untuk memahami berbagai masalah keuangan dan operasional yang dapat timbul (Zhang, et al., 2007). Teori agensi digunakan untuk membantu komite audit untuk memahami konflik kepentingan yang dapat muncul antara pemilik dan manajemen

Keberagaman jumlah anggota komite audit pada perusahaan publik di Indonesia bermacam-macam. Hal ini memunculkan pemikiran bahwa semakin banyak anggota komite audit dapat lebih cepat dalam menemukan serta menyelesaikan potensi masalah yang terjadi dalam proses pelaporan keuangan sehingga dapat megurangi audit report lag. Hasil penelitan yang dilakukan oleh ayu (2014) dan Haryani (2014) menyatakan bahwa ukuran komite audit berpengaruh pada audit report lag. Hasil penelitian tersebut sejalan dengan penelitian yang dilakukan oleh Gunarsa (2016) yang menyatakan bahwa ukuran komite audit berpengaruh negatif terhadap audit report lag. Semakin besar ukuran komite audit maka akan semakin meningkatkan kualitas pengawasan dan meminimalisir terjadinya audit report lag.

$\mathrm{H}_{1}$ : Ukuran Komite Audit berpengaruh negatif pada Audit Report Lag.

Teori dari hipotesis ini bertumpu pada teori agensi, dimana pihak pemilik (principal) termotivasi terhadap transparansi, tidak adanya kelalaian, dan ketepatan waktu yang dilakukan oleh manajer (agent). Dengan demikian, semakin banyak proporsi komite audit yang independen akan semakin berkurangnya orang yang tidak memiliki kepentingan apapun didalam perusahaan dan mengurangi adanya intervensi terhadap pengerjaan laporan.

Salah satu tujuan dari komite audit adalah untuk memberikan ulasan objektif tentang informasi keuangan, dan komite audit independen dapat berkontribusi terhadap kualitas pelaporan keuangan. Semakin banyak komite audit yang independen, maka akan semakin sedikit orang yang berkepentingan 
didalam perusahaan, sehingga semakin sedikit intervensi dan akan berfokus terhadap pengerjaan laporan yang dimana waktu tidak akan terbuang dalam pengerjaannya. Wardhani \& Raharja (2013) Independensi komite audit berpengaruh signifikan pada audit report lag dengan arah negatif, ini menunjukan bahwa semakin besar proporsi komite audit independen dapat memperpendek audit report lag. Perusahaan-perusahaan yang memiliki insentif serta kemampuan untuk meningkatkan komite audit, dengan cara memiliki komite audit independen lebih banyak dari jumlah yang disyaratkan oleh undang-undang. Pendapat yang sama juga dikemukakan oleh Hashim \& Rahman (2011) dan Kumara (2015) yang menyatakan bahwa independensi komite audit berpengaruh negatif pada audit report lag. Namun pendapat tersebut berbeda dengan hasil yang dikemukakan Noeryanto (2015), Nor, et al., (2010) dan Wijaya (2012) yang menyatakan bahwa independensi komite audit tidak berpengaruh pada Audit Report Lag. Berdasarkan uraian tersebut dapat ditarik hipotesis sebagai berikut. $\mathrm{H}_{2}$ : Independensi Komite Audit Berpengaruh Negatif pada Audit Report Lag.

Teori kepatuhan akan mendorong individu untuk lebih mematuhi peraturan yang berlaku. Hal tersebut berarti komie audit harus mematuhi aturan yang berlaku seperti peraturan kode etik, UU, termasuk Peraturan Bapepam no. IX.I.5 : Pembentukan dan Pedoman Pelaksanaan Kerja Komite Audit, Lampiran Keputusan Ketua Bapepam No: Kep29/PM/2004 yang diterbitkan pada 24 Desember 2004 mensyaratkan komite audit melakukan pertemuan sekurangkurangnya sama dengan ketentuan rapat dewan komisaris yang ditentukan dalam anggaran dasar perusahaan. Komite audit biasanya perlu untuk mengadakan pertemuan tiga sampai empat kali dalam satu tahun untuk melaksanakan kewajiban dan tanggungjawabnya. Intensitas pertemuan yang cukup tinggi oleh komite audit diharapkan dapat mempersingkat audit report lag.

Komite audit juga dapat mengadakan pertemuan eksekutif dengan pihakpihak luar antara lain komisaris, manajemen senior, kepala auditor internal dan kepala auditor eksternal. Hasil rapat komite audit dituangkan dalam risalah rapat yang ditandatangani oleh semua anggota komite audit. Ketua komite audit bertanggung jawab atas agenda dan bahan-bahan pendukung yang diperlukan serta wajib melaporkan aktivitas pertemuan komite audit kepada dewan komisaris. Apabila komite audit menemukan hal-hal yang diperkirakan dapat mengganggu kegiatan perusahaan, komite audit wajib menyampaikannya kepada dewan komisaris selambat-lambatnya sepuluh hari kerja.

Sari \& Ghozali (2014) dan Nor et al., (2010) menyatakan bahwa pertemuan komite audit berpengaruh negatif pada audit report lag. Penelitian tersebut tidak sejalan dengan hasil penelitian yang dilakukan Wijaya \& Surya (2012) yang menyatakanbahwa karakteristik komite audit berupa jumlah rapat komite audit tidak memiliki pengaruh yang signifikan terhadap audit report lag laporan keuangan.

$\mathrm{H}_{3}$ : Rapat Komite Audit Berpengaruh Negatif pada Audit Report Lag.

\section{METODE PENELITIAN}

Penelitian ini dilakukan pada seluruh perusahaan manufaktur yang terdaftar di Bursa Efek Indonesia (BEI) pada tahun 2014 - 2016 yang dapat diakses melalui www.idx.co.id. Variabel bebas dalam penelitian ini adalah komite audit $\left(\mathrm{X}_{1}\right)$, 
independensi komite audit $\left(\mathrm{X}_{2}\right)$, rapat komite audit $\left(\mathrm{X}_{3}\right)$. Variabel terikat dalam penelitian ini adalah audit report lag $(\mathrm{Y})$.

Populasi yang digunakan dalam penelitian ini adalah perusahaan manufaktur yang terdaftar di Bursa Efek Indonesia (BEI) tahun 2014-2016. Alasan peneliti menggunakan perusahaan manufaktur dikarenakan mayoritas perusahaan yang go public di BEI merupakan jenis perusahaan manufaktur dan memiliki berbagai macam industri yang dapat mewakili semua perusahaan. Peneliti juga ingin meminimalisasi bias akibat perbedaan jenis industri. Sampel adalah bagian dari jumlah karakteristik yang dimiliki oleh populasi tersebut (Sugiyono, 2017:80). Sampel dalam penelitian ini, perusahaan manufaktur tahun 2014-2016 yang terdafatar di Bursa Efek Indonesia (BEI).

Metode pengumpulan data yang digunakan dalam penelitian ini adalah observasi non partisipan, yaitu metode teknik pengumpulan data dengan cara membaca, mengamati, mencatat, dan mempelajari uraian-uraian dari dokumen yang berhubungan dengan penelitian (Sugiyono, 2016:173). Teknik analisis data yang digunakan dalam penelitian ini adalah uji asumsi klasik dan analisis regresi linier berganda. Dimana regresi linier berganda ini merupakan alat analisis yang digunakan untuk mengukur pengaruh lebih dari satu variabel independen terhadap variabel dependen. Model regresi dirumuskan dengan persamaan berikut:

$$
Y=\alpha+\beta_{1} X_{1}+\beta_{2} X_{2}+\beta_{3} X_{3}+\varepsilon
$$

Keterangan :

$\begin{array}{lll}\mathrm{Y} & : & \text { Audit Report Lag } \\ \mathrm{a} & : & \text { Konstanta } \\ \mathrm{b}_{1,} \mathrm{~b}_{2}, \mathrm{~b}_{3} & : & \text { Koefisien regresi variabel independen } \\ \mathrm{X}_{1} & : & \text { Komite Audit } \\ \mathrm{X}_{2} & : & \text { Independensi Komite Audit } \\ \mathrm{X}_{3} & : & \text { Rapat Komite Audit } \\ \varepsilon & : & \text { error }\end{array}$

\section{HASIL DAN PEMBAHASAN}

Statistik deskriptif berhubungan dengan pengumpulan dan peringkat data yang menggambarkan karakteristik sampel yang digunakan dalam penelitian ini. Analisis ini berguna untuk menjelaskan karakteristik sampel terutama mencakup jumlah amatan, nilai ektrim yaitu nilai minimum dan maksimum, nilai rata-rata (mean), serta standar deviasi dari masing-masing variabel. Hasil dari statistik deskriptif tersebut dapat dilihat pada Tabel 1.

Tabel 1. Hasil Statistik Deskriptif

\begin{tabular}{llllll}
\hline Variabel & $\mathrm{N}$ & Minimum & Maximum & Mean & $\begin{array}{l}\text { Std. } \\
\text { Deviation }\end{array}$ \\
\hline Ukuran Komite Audit $\left(\mathrm{X}_{1}\right)$ & 132 & 3,00 & 5,00 & 3,1667 & 0,43099 \\
Independensi Komite Audit $\left(\mathrm{X}_{2}\right)$ & 132 & 0,33 & 0,75 & 0,6329 & 0,09380 \\
Rapat Komite Audit $\left(\mathrm{X}_{3}\right)$ & 132 & 3,00 & 33,00 & 6,9242 & 5,65094 \\
Audit Report Lag $(\mathrm{Y})$ & 132 & 43,00 & 89,00 & 74,8409 & 11,58495 \\
Valid N (listwise) & 132 & & & & \\
\hline
\end{tabular}

Sumber: Data Penelitian, 2018 
Nilai minimum untuk audit report lag adalah 43,00 dan nilai maksimumnya adalah 89,00. Mean dari audit report lag adalah 74,8409. Hal ini berarti rata-rata audit report lag perusahaan manufaktur yang terdftar di BEI yang diamati selama tahun 2014-2016 sebesar 74,8409. Standar deviasi untuk audit report lag adalah 11,58495. Artinya terjadi penyimpangan nilai audit report lag terhadap nilai rataratanya sebesar 11,58495 .

Nilai minimum untuk Ukuran Komite Audit adalah 3,00 dan nilai maksimumnya adalah 5,00. Mean dari ukuran komite audit adalah 3,1667. Hal ini berarti rata-rata ukuran komite audit perusahaan manufaktur yang terdaftar di BEI yang diamati selama tahun 2014-2016 sebesar 3,1667. Standar deviasi untuk ukuran komite audit adalah 0,43099. Artinya terjadi penyimpangan nilai ukuran komite audit terhadap nilai rata-ratanya sebesar 0,43099.

Nilai minimum untuk independensi komite audit adalah 0,33 dan nilai maksimumnya adalah 0,75. Mean dari independensi komite audit adalah 0,6329. Hal ini berarti rata-rata independensi komite audit perusahaan manufaktur yang terdaftar di BEI yang diamati selama tahun 2014-2016 sebesar 0,6329. Standar deviasi untuk independensi komite audit 0,09380. Artinya terjadi penyimpangan nilai independensi komite audit terhadap nilai rata-ratanya sebesar 0,09380.

Nilai minimum untuk rapat komite audit adalah 3,00 dan nilai maksimumnya adalah 33,00. Mean dari rapat komite audit adalah 6,9242. Hal ini berarti rata-rata rapat komite audit perusahaan manufaktur yang terdaftar di BEI yang diamati selama tahun 2014-2016 sebesar 6,9242. Standar deviasi untuk rapat komite audit adalah 5,65094. Artinya terjadi penyimpangan nilai rapat komite audit terhadap nilai rata-ratanya sebesar 5,65094.

Analisis regresi linier berganda digunakan untuk mengetahui besarnya pengaruh Ukuran Komite Audit $\left(X_{1}\right)$, Independensi Komite Audit $\left(X_{2}\right)$, dan Rapat Komite Audit $\left(\mathrm{X}_{3}\right)$ pada Audit Report Lag $(\mathrm{Y})$ di perusahaan manufaktur yang terdaftar di Bursa Efek Indonesia. Hasil olahan data dengan SPSS menggunakan model analisis regresi linier berganda dapat dilihat sebagai berikut.

Tabel 2. Hasil Analisis Regresi Linier Berganda

\begin{tabular}{|c|c|c|c|c|c|}
\hline \multirow[t]{2}{*}{ Model } & \multicolumn{2}{|c|}{$\begin{array}{l}\text { Unstandardized } \\
\text { Coefficients }\end{array}$} & \multirow{2}{*}{$\begin{array}{l}\text { Standardized } \\
\text { Coefficients } \\
\text { Beta }\end{array}$} & \multirow[t]{2}{*}{$\mathrm{T}$} & \multirow[t]{2}{*}{ Sig. } \\
\hline & $\mathrm{B}$ & Std. Error & & & \\
\hline (Constant) & 79,030 & 12,698 & & 6,224 & 0,000 \\
\hline $\mathrm{X}_{1}$ & $-7,220$ & 3,031 & -269 & $-2,382$ & 0,019 \\
\hline$X_{2}$ & 25,579 & 10,849 & 0,207 & 2,358 & 0,020 \\
\hline$X_{3}$ & 0,359 & 0,222 & 175 & 1,619 & 0,108 \\
\hline
\end{tabular}

Sumber: Data Penelitian, 2018

Dari hasil analisis regresi linier berganda pada Tabel 2, dapat dibuat persamaan sebagai berikut.

$$
\mathrm{Y}=79,030-7,220 \mathrm{X}_{1}+25,579 \mathrm{X}_{2}+0,359 \mathrm{X}_{3}+\varepsilon
$$

Berdasarkan persamaan regresi di atas dapat dijelaskan bahwa nilai konstanta (a) sebesar 79,030 berarti apabila variabel bebas yaitu ukuran komite audit, indepedensi komite audit, dan rapat komite audit sama dengan nol, maka Audit report lag meningkat sebesar 79,030 satuan.

Nilai koefisien regresi ukuran komite audit $\left(\beta_{1}\right)$ sebesar $(-7,220)$ berarti apabila ukuran komite audit menurun sebesar 1 satuan dengan anggapan 
variabel lainnya konstan, maka Audit report lag akan menurun sebesar 7,220 satuan.

Nilai koefisien regresi independensi komite audit $\left(\beta_{2}\right)$ sebesar 25,579 berarti apabila independensi komite audit meningkat sebesar 1 satuan dengan anggapan variabel lainnya konstan, maka Audit report lag akan meningkat sebesar 25,579 satuan.

Nilai koefisien regresi rapat komite audit $\left(\beta_{3}\right)$ sebesar 0,359 berarti apabila ukuran perusahaan meningkat sebesar 1 satuan dengan anggapan variabel lainnya konstan, maka Audit report lag akan meningkat sebesar 0,359 satuan.

Uji statistik $F$ bertujuan untuk mengetahui variabel bebas yang digunakan dalam persamaan regresi yaitu ukuran komite audit, independensi komite audit, dan rapat komite audit secara bersama-sama mampu menjelaskan variabel terikatnya yaitu audit report lag . Berikut hasil Uji F yang diolah menggunakan SPSS yang disajikan dalam Tabel 3.

Tabel 3. Hasil Uji Kelayakan Model (Uji F)

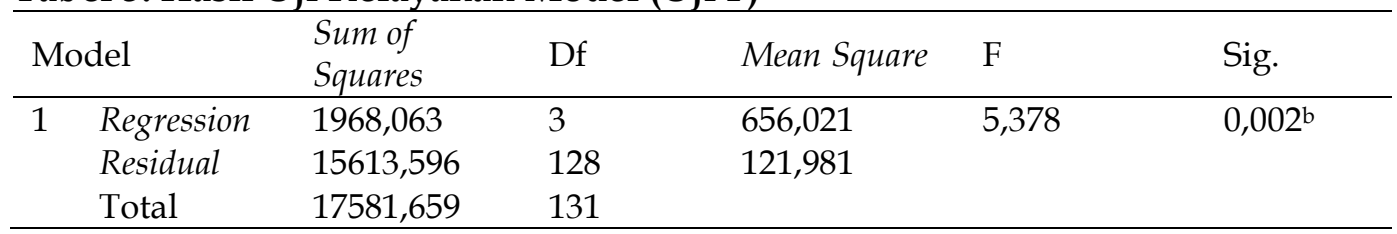

Sumber: Data Penelitian, 2018

Tabel 3, menunjukkan bahwa nilai $F_{\text {hitung }}$ sebesar 5,378 dengan signifikansi $F$ sebesar 0,002 yang lebih kecil dari nilai $a=0,05$ maka menunjukkan bahwa ukuran komite audit, independensi komite audit, dan rapat komite audit secara simultan berpengaruh terhadap audit report lag serta model regresi linier berganda layak digunakan sebagai alat analisis dalam penelitian ini.

Koefisien determinasi pada intinya mengukur seberapa jauh kemampuan model dalam menerangkan variasi variabel dependen (Ghozali, 2012:97). Nilai koefisien determinasi adalah antara nol dan satu. Nilai Adjusted $R^{2}$ yang kecil berarti kemampuan variabel-variabel indepeden dalam mejelaskan variasi variabel dependen amat terbatas. Nilai yang mendekati satu berarti variabelvariabel independen memberikan hampir semua informasi yang dibutuhkan untuk memprediksi variasi variabel dependen (Ghozali, 2012:97). Berikut ini adalah koefisien determinasi dari penelitian ini yang disajikan dalam Tabel 4.

Tabel 4. Hasil Koefisien Determinasi

\begin{tabular}{lllll}
\hline Model & $\mathrm{R}$ & $\mathrm{R}$ Square & Adjusted $\mathrm{R}$ Square & $\begin{array}{l}\text { Std. Error of the } \\
\text { Estimate }\end{array}$ \\
\hline 1 & $0,335^{\mathrm{a}}$ & 0,112 & 0,091 & 11,04451 \\
\hline
\end{tabular}

Sumber: Data Penelitian, 2018

Dari Tabel 4, menunjukkan bahwa nilai Adjusted $R^{2}$ adalah sebesar 0,091 berarti bahwa variasi variabel independen mampu menjelaskan $9,1 \%$ variasi variabel dependen, sedangkan sisanya yaitu sebesar 90,9\% dijelaskan oleh variabel lain diluar variabel independen.

Uji statistik $\mathrm{t}$ bertujuan untuk mengetahui variabel bebas yang digunakan dalam persamaan regresi yaitu rpat komite auudit, independensi komite audit, dan rapat komite audit secara individual (parsial) mampu menjelaskan variabel 
terikatnya yaitu audit report lag. Berikut ini adalah hasil Uji $t$ dari penelitian ini disajikan dalam Tabel 5.

Tabel 5. Hasil Uji Hipotesis (Uji t)

\begin{tabular}{lll}
\hline Model & $\mathrm{T}$ & Sig. \\
\hline (Constan) & 6,224 & 0,000 \\
Ukuran Komite Audit $\left(\mathrm{X}_{1}\right)$ & $-2,382$ & 0,019 \\
Independensi Komite Audit $\left(\mathrm{X}_{2}\right)$ & 2,358 & 0,020 \\
Rapat Komite Audit $\left(\mathrm{X}_{3}\right)$ & 1,619 & 0,108 \\
\hline
\end{tabular}

Sumber: Data Penelitian, 2018

Berdasarkan Tabel 5, maka hasil pengujian pengaruh masing-masing variabel independen yaitu berdasarkan Tabel 5, pada persamaan diperoleh nilai signifikansi Uji t untuk variabel ukuran komite audit sebesar $(-2,382)$ dan tingkat signifikansi sebesar $=0,019$ berarti lebih kecil dari tingkat signifikansi sebesar 0,05. Menunjukkan variabel ukuran komite audit berpengaruh pada Audit report lag. Dengan kata lain $\mathrm{H}_{1}$ diterima.

Jadi, semakin banyak anggota komite audit dapat lebih cepat dalam menemukan serta menyelesaikan potensi masalah yang terjadi dalam proses pelaporan keuangan sehingga dapat megurangi audit report lag. Hasil penelitan yang dilakukan oleh Ayu (2014) dan Haryani (2014) menyatakan bahwa ukuran komite audit berpengaruh pada audit report lag. Hasil penelitian tersebut sejalan dengan penelitian yang dilakukan oleh Gunarsa (2016).

Berdasarkan Tabel 5, pada persamaan diperoleh nilai signifikansi Uji t untuk variabel independensi komite audit sebesar 2,358 dan tingkat signifikansi $=0,020$ yang berarti lebih kecil dari tingkat signifikansi sebesar 0,05 Menunjukkan variabel independensi komite audit berpengaruh pada audit report lag. Dengan kata lain $\mathrm{H}_{2}$ ditolak.

Semakin besar proporsi independensi komite audit kemungkinan tidak memperpendek audit report lag. Proporsi independensi komite audit yang besar akan semakin meningkatkan pengawasan dan memerlukan waktu yang lebih dalam kualitas pelaporan keuangan sehingga independensi komite audit berpengaruh positif terhadap audit report lag. Hasil penelitian ini sejalan dengan penelitian sebelumnya oleh Noeryanto (2015) dan Wardhani (2013) yang menyatakan bahwa independensi komite audit berpengaruh signifikan pada Audit Report Lag.

Berdasarkan Tabel 5, pada persamaan diperoleh nilai signifikansi Uji t untuk variabel ukuran perusahaan sebesar 1,619 dan tingkat signifikansi $=0,108$ yang berarti lebih besar dari tingkat signifikansi sebesar 0,05 Menunjukkan variabel rapat komite audit tidak berpengaruh pada audit report lag. Dengan kata lain $\mathrm{H}_{3}$ ditolak.

Hal ini berarti bahwa meskipun semakin banyak jumlah pertemuan anggota komite audit pada perusahaan ternyata tidak membedakan dengan perusahaan yang hanya beberapa kali melakukan pertemuan. Hasil penelitian ini sejalan dengan penelitian yang dilakukan oleh Hashim dan Rahman (2011) dan Wijaya (2012) yang menunjukan bahwa jumlah rapat komite audit tidak berpengaruh terhadap audit report lag.

Penelitian ini menghasilkan simpulan mengenai bagaimana pengaruh ukuran komite audit, independensi komite audit, dan rapat komite audit pada 
audit report lag. Hasil dari penelitian ini menjelaskan bahwa ukuran komite audit berpengaruh negatif audit report lag dan independensi komite audit berpengaruh positif terhadap audit report lag. Penelitian ini dapat menambahkan bukti empiris serta menambah wawasan mengenai pengaruh ukuran komite audit, independensi komite audit, rapat komite audit pada audit report lag. Penelitian ini dapat memperkuat teori agensi bahwa teori agensi digunakan untuk membantu komite audit agar dapat memahami konflik kepentingan yang dapat muncul antara pemilik dan manajemen dengan hasil penelitian yang menunjukan adanya pengaruh antara ukuran komite audit terhadap audit report lag. Namun independensi komite audit dan rapat komite audit belum dapat menunjukan dan menjadi acuan untuk memahami konflik kepentingan yang dapat muncul antara pemilik dan manajemen.

Rapat komite audit belum sesuai dengan teori kepatuhan yang akan mendorong individu untuk lebih mematuhi peraturan yang berlaku. Hal tersebut berarti komite audit harus mematuhi aturan yang berlaku seperti peraturan kode etik, UU, termasuk Peraturan Bapepam no. IX.I.5 : Pembentukan dan Pedoman Pelaksanaan Kerja Komite Audit, Lampiran Keputusan Ketua Bapepam No: Kep29/PM/2004 yang diterbitkan pada 24 Desember 2004 mensyaratkan komite audit melakukan pertemuan sekurang-kurangnya sama dengan ketentuan rapat dewan komisaris yang ditentukan dalam anggaran dasar perusahaan.

Penelitian ini diharapkan akan memberikan kontribusi positif bagi semua pihak khususnya pihak perusahaan dan manajemen untuk memahami konflik kepentingan yang ada di perusahaan sesuai dengan teori agensi dan teori kepatuhan. Bagi pihak perusahaan hendaknya mematuhi aturan yang berlaku seperti peraturan kode etik, UU, termasuk Peraturan Bapepam no. IX.I.5 tentang Pembentukan dan Pedoman Pelaksanaan Kerja Komite Audit, Lampiran Keputusan Ketua Bapepam No: Kep29/PM/2004 yang diterbitkan pada 24 Desember 2004 mensyaratkan komite audit melakukan pertemuan sekurangkurangnya sama dengan ketentuan rapat dewan komisaris yang ditentukan dalam anggaran dasar perusahaan.

\section{SIMPULAN}

Berdasarkan hasil analisis dan pembahasan yang telah dipaparkan, maka daoat disimpulkan bahwa ukuran komite audit berpengaruh negatif pada audit report lag. Independensi komite audit berpengaruh positif pada audit report lag. Rapat komite audit tidak berpengaruh pada audit report lag

Berdasarkan simpulan di atas, saran-saran yang dapat diberikan berkaitan dengan hasil penelitian serta untuk kesempurnaan penelitian selanjutnya yaitu bagi peneliti selanjutnya diharapkan memasukan variabel lain yang dapat mempengaruhi audit report lag, ataupun memasukan variabel intervening sehingga dapat mengetahui faktor apa yang dapat memperkuat atau memperlemah variabel audit report lag. Penelitian selanjutnya sebaiknya menambah periode penelitian.

Bagi perusahaan di Indonesia diharapkan agar mempersiapkan laporan keuangan berserta dokumen pendukung sesuai dengan regulasi yang ditetapkan 
oleh regulator. Hal ini bertujuan membantu auditor dalam mempercepat proses audit.

\section{REFERENSI}

Abdelsalam, O. \& Street, D. (2007). Corporate governance and the timeliness of corporate internet reporting by UK listed companies. Journal of International Accounting, Auditing and Taxation, 16 (2), hal.111-130.

Afify, H.A.E. (2009). Determinants of Audit Report Lag : Does implementing corporate governance have any impact ? Empirical Evidence from Egypt. Journal of Applied Accounting Research, 10(1), hal: 56-86.

Ahmed, Alim Al Ayub and Md. Shakawat Hossain. (2010). Audit Repot Lag: A Study of the Bangladeshi Listed Companies. Journal ASA University Review. 4(2).

Antle and Nalebuff. (1991). Conservatismand Auditor - Client Negotiations. Journal of Accounting Research, hal.31-54.

Asri Dwija Putri, I Gusti Ayu Made. (2012). Pengaruh Kebijakan Deviden dan Good Corporate Governance terhadap Manajemen Laba. AUDI: Jurnal Akuntansi dan Bisnis. 17(2), Hal. 156-169.

Ayu Evryani Rianti, Ni Luh Putu. (2014). Karakteristik Komite Audit dan Audit Delay. Jurnal Akuntansi Universitas Udayana, Bali. 6(3)

Azibi, J., Tondeur, H., dan Rajhi, M. T. (2008). Auditor Choice and Intitutionel Investor Characteristics After Enron Scandal in The French Context. Journal of Accounting and Economics. Hal. 48-76.

Bamber, E.L., and Schoderbek. (1993). Audit Structure and Other Determinants of Audit Report Lag: An Empirical Analysis. Journal of Practise and Theory. 12(1), Hal. 1-23.

Bapepam. (2003). Kewajiban Penyampaian Laporan Keuangan Berkala, Keputusan Ketua Bapepam No. Kep-36/PM/2003 tanggal 30 September 2003 tentang Peraturan Nomor X.K.2.

Bapepam. (2004). Pembentukkan dan Pedoman Pelaksanaan Kerja Komite Audit, Keputusan Ketua Bapepam No. Kep-29/PM/2004 tanggal 24 Desember 2004 tentang Peraturan Nomor IX.1.5.

Bonson-Ponte, E., Escobar-Rodríguez, T. and Borrero-Domínguez, C. (2008). 'Empirical Analysis of Delay in the Signing of Audit Reports in Spain', International Jornal of Auditing, 12, hal.129-140.

Bursa Efek Jakarta. (2000). Pemberlakuan Komite Audit, Keputusan direksi Bursa Efek Jakarta No: Ke-315/BEJ/06/2000.

Choi, J., K. Jeon and J. Park, (2004), The role of audit committees in decreasing earnings management: Korean evidence, International Journal of Accounting, Auditing and Performance Evaluation 1, hal. 37-60.

Dewiyani Swami, Ni Putu. (2013). Pengaruh Karakteristik Corporate Governace terhadap Audit Report Lag. Jurnal. Fakultas Ekonomi dan Bisnis Universitas Udayana, Bali.

DeZoort, F. Todd and Steven E. Salterio. (2001). The Effects of Corporate Governance Experience and Financial-Reporting and Audit Knowledge on Audit Committee Members Judgment. Auditing: A Journal of Practice and Theory. 20(2), hal. 31-47. 
Djakman dan Chaerul, D. (2003). Manajemen Laba dan Pengaruh Kebijakan Multi Papan Bursa Efek Jakarta. Simposium Nasional Akuntansi VI, Surabaya 16-17 Oktober

Dyer, J.C. and Athur Mc. Hugh. (1975). The Timeliness of The Australian Annual Report. Journal of Accounting Research. Hal. 204-219.

Gunarsa, I Gede Aditya Cahya. (2016). Pengaruh Komite Audit, Independensi Komite Audit dan Profitabilitas terhadap Audit Report Lag. Jurnal Akuntansi Universitas Udayana, Bali.

Hashim, and Rahman. (2011). Audit report lag and the Effectiveness of Audit Committee Among Malaysian Listed Companies. International Bulletin of Business Administration ISSN: 1451-243X Issue 10 (2011) (C) EuroJournals, Inc. 2011 http://www.eurojournals.com

Haryani, Jumratul. (2014). Pengaruh Ukuran Perusahaan, Komite Audit, Penerapan International Financial Reporting Standards dan Kepemilikan Publik pada Audit Delay. Jurnal Akuntansi Universitas Udayana, Bali.

Ikatan Akuntansi Indonesia (IAI). (2012). Standar Akuntansi Keuangan. Jakarta: Salemba Empat.

Indriyani, Rosmawati Endang. (2012). Faktor-faktor yang mempengaruhi Audit Report Lag Perusahaan Manufaktur di Indonesia dan Malaysia. Jurnal Universitas STIE Perbanas, Surabaya.

Jensen, Michael C. dan Meckling William H. (1976). Theory of The Firm : Managerial Behavior, Agency Cost and Ownership Structure. Journal of Financial Economics October, 3(4) hal. 305-360.

Khasharmeh, H. A., and Aljifri, K. (2010). The Timeliness of Annual Reports in Bahrain and the United Arab Emirates: An Empirical Comparative Study. The International Journal of Business and Finance Research, 4, hal. 5171.

Kirk, D. J. (2000). Experience with the Public Oversight Board and corporate audit committees. Accounting Horizons, 14(1), 103-111

Knechel, D.M. dan Peyne J.L. (2001). Additional Evidence on Audit Repor Lag, Auditing: A Journal Practice and theory.

Kumara, Raditya Andika. (2015). Pengaruh Good Corporate Governance Terhadap Audit Report Lag (Studi Kasus pada Perusahaan Manufaktur yang Terdaftar di Bursa Efek Indonesia Tahun 2010-2013). Skripsi. Fakultas Ekonomika dan Bisnis Universitas Diponegoro, Semarang.

Lianto, Novice dan Budi Hartono Kusuma. (2010). Faktor-Faktor yang Berpengaruh Terhadap Audit Report Lag. Jurnal Bisnis dan Akuntansi Universitas Tarumanegara. 12(2), hal: 97-106.

Megayanti, Putu. (2015). Pengaruh Pergantian Auditor, Ukuran Perusahaan, Laba Rugi dan Jenis Perusahaan pada Audit Report Lag (Studi pada Perusahaan yang Terdaftar di Bursa Efek Indonesia Tahun 2013 dan 2014). Jurnal Akuntansi Universitas Udayana, Bali.

Mulyadi. (2002). Auditing. Universitas Gajah Mada. Yogyakarta: Salemba Empat

Naimi, Mohammad., Rohami Shafie. and Wan Nordin Wan-Hussin. (2010). Corporate Governance and Audit Report Lag in Malaysia, Asian Academy of management journal of Accounting and Finance, Vol 6, 57-84. 
Noeryanto, Handy. (2015). Faktor - Faktor yang Berpengaruh terhadap Audit Report Lag pada Perusahaan Keuangan. Jurnal. STIE Trisakti, Jakarta.

Nor, Shafie, and Hussin. (2010). Corporate Governance and Audit report lag in Malaysia. Asian Accademy of Managerial Journal of Accounting and Finance, 6(2), hal.57-84.

Petronila, Thio Anastasia. (2007). "Analisis Skala Perusahaan, Opini Audit, dan Umur Perusahaan Atas Audit Delay". Akuntabilitas, 6(2), hal.129-141.

Rahardja, Budi. (2001). Akuntansi dan Keuangan untuk Manajer Nonkeuangan. Yogyakarta: Graha Ilmu.

Sari, Revani Ratna dan Imam Ghozali. (2014). Faktor - Faktor Pengaruh Audit Report Lag (Kajian Empiris Pada Perusahaan Manufaktur yang Terdaftar di Bursa Efek Indonesia Tahun 2010-2012). Diponegoro Journal of Accounting, 3(2), hal.1-9.

Suaryana, Agung. (2007). Pengaruh Komite Audit Terhadap Kualitas Laba. Jurnal Ilmiah akuntansi dan Bisnis Universitas Udayana. 2(1)

Sugiyono. (2016). Metode Penelitian Kuantitatif Kualitatif \& RND. Alfabeta, Bandung

Sukrisno Agoes. (2012). Auditing Edisi 4. Jakarta: Salemba Empat.

Toding, Merlina. (2013). Faktor-faktor yang Memengaruhi Ketepatwaktuan Penyampaian Laporan Keuangan. Jurnal Akuntansi Udayana, Bali.

Wardhani, Armania Putri dan Surya Raharja. (2013). Analisis Pengaruh Corporate Governance Terhadap Audit Report Lag. Diponegoro Journal of Accounting. 2(3).

Wijaya, Taruna Aditya dan Surya Rahardja. (2012). Pengaruh Karakteristik Komite Audit Terhadap Audit Report Lag: Kajian Empiris pada Perusahaan yang Terdaftar di Bursa Efek Indonesia Tahun 2010. Jurnal Ekonomi Universitas Diponegoro, Semarang. 